\title{
Ton!k WANITA PEKERJA KERAS DALAM KARYA SENI LUKIS REALIS KONTEMPORER
}

Volume 2, Nomor 2 Juli 2020, (73-80)

\section{Seftian Hidayat}

Penciptaan Seni Lukis, Program Penciptaan dan Pengkajian Pascasarjana Institut Seni Indonesia Yogyakarta e-mail : Seftianh0@gmail.com

\begin{abstract}
ABSTRAK
Tujuan memvisualisasikan karya seni lukis realis kontemporer yang di latar belakangi persoalan situasi dan kondisi sosial masyarakat khususnya wanita pekerja keras. Wanita secara peranannya menjadi ibu rumah tangga mengurus keluarga, menjadi sosok gugru bagi anak-anaknya namun memilih berkerja keras dalam memenuhi kebutuhan ekonomi hal yang tak lazim bagi seorang wanita yang menilih pekerjaan yang tidak sesuai dengan sifat dan peranan wanita pada umumnya, hal tersebut yang menyebabkan rasa emansipasi yang timbul terhadap seorang wanita faktor ekonomi menjadi hal yang utama bagi seorang keluarga yang mengharuskan masalah itu terjadi kesanggupan seorang wanita yang membagi peranannya dalam dua hal yakni sebagai ibu rumah tangga dan sebagai pencari nafkah. Metode dan proses pencitaan karya seni lukis melalui beberapa tahap yakni tahap persiapan, tahap elaborasi, tahap sintesis, tahap relasasi konsep dan tahap penyelesaian. Penggunaan metode yang di pakai yakni peraktik berbasis risert Penelitian berbasis praktik merupakan penelitian yang dimulai dari pengumpulan data-data dari observasi lapangan sampai kerja praktik, pemahaman in and trough dengan arti penelitian yang dilakukan tidak hanya sebatas praktik tetapi meneliti sesuatu. Karya yang divisualkan yaitu: Melawan Rasa Lelah, Demi Cita-Cita, Mengisi Satu Demi Satu, Harapan Dibalik Senyuman, Menjadi Tulang Punggung, Perjuangan Yang Takberujung, Mengais Satu Demi Satu, Melawan Rasa, Angan-Angan Yang Tinggi, Harapan Yang Indah.
\end{abstract}

Kata Kunci: Wanita, Pekerja, Keras, Realis, Kontemporer,Sosial.

\begin{abstract}
The purpose of visualizing the work of contemporary realist painting in the background of the issue of the situation and social conditions of society, especially hard-working women. Women play a role as housewives to take care of the family, be a figure of gut for his children however choosing to work hard in meeting the needs of the economy unusual thing for a woman who chooses a job that is not in accordance with the nature and role of women in general, it causes a sense of emancipation that arises towards a woman economic factors become the main thing for a family that requires the problem occurs the ability of a woman who divides her role in two things namely as a housewife and as a breadwinner. Methods and process of painting through several stages of preparation stage, elaboration stage, synthesis stage, concept relasation phase and completion stage. The use of the method used is risk-based tactics. Practice-based research is research that starts from collecting data from field observations to practical work, understanding in and trough with the meaning that research is not only limited to practice but researches something. The works that are visualized are: Fighting Tiredness, For the Ideal, Filling One By One, Hope Behind Smile, Being Backbone, Endless Struggle, Scraping One by One, Against Pain, High Angle, Beautiful Hope.
\end{abstract}

Keywords: Women, Workers, Hard, Realists, Contemporary, Social

\section{PENDAHULUAN}

Tuhan menciptakan manusia begitu sempurna dan mulia dibandingkan dengan makhluk hidup lainya. Pria dan wanita diciptakan berpasangan agar terbentuknya suatu keturunan hingga menciptakan suatu keluarga yang utuh. Dalam keluarga terdiri dari ayah, ibu, dan anak yang masing-masing memiliki peranan tersendiri. Peranan wanita dalam lingkungan keluarga sangat fundamental. Dalam islam kaum wanita memiliki kedudukan dan kehormatan yang sangat mulia serta tidak adanya perbedaan hak baginya. Alqur'n menjelaskan peranan seorang wanita sangatlah penting, namun itu semua tidak keluar dari garis yang telah dikodratkan kepadanya. Wanita ibarat lembaga pendidikan bagi seorang anak. Anak yang dilahirkan berhak memperoleh pendidikan dari seorang ibu, karena utama wanita adalah sebagai ibu dan sebagai pengatur rumah tangga.

Mustafah (1997:50) menyatakan pada masa lampau yang telah diketahui secara umum 
fungsi wanita adalah mengurus rumah tangga memebsarkan anak-anak serta mengurus kepentingan suami dan urusan-urusan lain yang berkenaan dengan kehidupan rumah tangga. Sedikit sekali wanita yang di bebani masalahmasalah ekonomi sebagai mana yang mereka alami sekarang. Kalaupun ada wanita yang berkerja dia akan lebih banyak mengunakan waktunya untuk kepentingan keluarga dibandingkan waktu yang digunakan untuk kepentingan pekerjaannya. Hal ini berdampak positif dan negatif. Dampak positif terhadap wanita yang bekerja akan meningkatkan kepercayaan diri, kopetensi dan rasa kebanggaan sebagai pekerja. Dampak negative yang terjadi yakni meningktkan resiko terjerumusnya anakanak kepada hal yang negatif suami memiliki perasaan yang tersaingi dan tidak terpenuhinya hak-hak sebagai suami, bertambahnya pengangguran untuk pria dikarnakan pekerjaan yang diambil ahli.

Kecenderungan untuk bekerja di luar rumah jelas akan membawa konsekuensi sekaligus berbagai dampak sosial, antara lain meningkatnya kenakalan remaja akibat kurangnya perhatian orang tua, dan melonggarnya nilai-nilai ikatan perkawinan keluarga.Keberadaan wanita yag bekerja tentunya alsan tersendiri yakni menganggap bahwa wanita bias menyamakan kedudukannya seperti laki-laki dan untuk memenuhi kebutuhan keluarga untuk membantu suami agar kebutuhan tersebut terpenuhi.Pemenuhi kebutuhan dunia wanita yang bekerja menggantikan peran seorang suami sebagai pencari nafkah bagi keluarga, wanita juga bisa mencari nafkah dengan bekerja sebagai buruh, pedagang, dan petani

Figure seorang wanita yang bekerja dengan digantikan pekerjaan seorang laki-laki menjadikan satu motivasi agar dapat bersyukur dan sebagai pelajaran. Dengan menampilkan sesosok wanita yang bekerja secara visual dan melalui bahasa rupa tentunya dapat menjadikan sesuatu penyampaian

kegelisahan penulis yang dijumpai, menjadi jalan Penyampaian pesan melalui media visual yang dapat disampaikan kepada para penikmat seni dan masyarakat umum. Ernawati, E. (2020) dalam atikel yang berjudul PSIKOLOGIS DALAM SENI: KATARSIS SEBAGAI REPRESENTASI DALAM KARYA SENI RUPA mengungkapkan bahwa manusia memiliki cara yang unik dan bervariasi dalam melakukan katarsis sebagai proses pelepasan emosi, begitupun dengan seniman melalui katarsis seakan menceritakan masalah yang dialaminya melalui citra visual yang dihadirkan dalam karya. Berkarya dengan berangkat dari kegelisahan tidak dapat dipungkiri, sering menjadi cerita sebagai babak awal terciptanya karya yang bersifat mengakar dan kuat Begitupun halnya yang terjadi dengan pencipta karya sekalius penulis, Melalui karya seni lukis dapat menyampaikan permasalahan dan kegelisahan secara visual agar dapat tersampaikan. Melalui karya seni lukis apresiator ataupun penikmat seni dapat mengmatinya secara visual. Pada tahap tersebut penyampaian kegelisahan yakni wanita sebagai pekerja keras melalui media lukis dengan mengunakan gaya realis kontemporer. Dengan memvisualisasikan objek lukis dengan tema wanita pekerja melalui gaya realis kontemporer, tentunya dapat menarik perhatian, bias mengkaji serta mendalami maksud dan tujuan yang akan disampakan. Wanita yang seharusnya menjadi ibu rumah tangga mengurus keluarga, mendidik dan mebesarkan anak. Bermual dari berbagai macam bentuk permasalahan yang penulis alami dengan alasan inilah penulis mendapatkan sumber ide sebagai ungkapan dan kegelisahan yang dituangkan dalam karya akhir dengan judul Wanita Pekerja Keras dalam Karya Seni Lukis Realis Kontemorer.

\section{METODE PENCIPTAAN}

Berdasarkan proses kreatif yang menjadi pengalaman penulis sebagai kalangan kreator akademis, dalam setiap pembentukan karya yang diciptakan, penulis melakukan pendekatan metode tahapan kerja. Maka metode yang penulis gunakan adalah metode Practice Based Research.

Penelitian berbasis praktik merupakan penelitian yang dimulai dari pengumpulan datadata dari observasi lapangan sampai kerja praktik. Penelitian berbasis praktik merupakan penyelidikan orisinil yang dilakukan guna memperoleh pengetahuan baru melalui praktik dan hasil praktik tersebut. Selain itu penulis juga mengikuti pemahaman in and trough dengan arti penelitian yang dilakukan tidak hanya sebatas praktik tetapi meneliti sesuatu juga belajar dengan sesuatu, tidak membaca membaca sesuatu tetapi melihat bersama sesuatu. Hal terpenting untuk ditelusuri secara utuh yaitu konsep penciptaan itu sendiri, karena konsep menjadi dasar utama penciptaan. Selain data yang diperoleh dari pengamatan penelitian juga dilakukan dengan studi kepustakaan pada beberapa dokumen dan buku yang berkaitan dengan tema yang penulis ambil.

Hannula, (2005:114),dalam bukunya artistic research menjelaskan enam kerangka penelitian artistik sebagai pertimbangan penulis:

1) Membuat klarifikasi subjek dan
menitikberatkan (pendahuluan/latar belakang,). Latar beakang mengapa penulis melakukan penelitian artistik 
ini untuk suatu objek tertentu dengan memberi alasan.

2) Membuka pre-asumsi pada subject matter dan sudut pandang.

3) Kepemilikan alat-alat penelitian, sehingga secara tajam menunjukkan perbedaan dengan penelitian lain.

4) Presentasi pustaka.

5) Evaluasi akhir, kesimpulan yang harus membawa hal-hal yang baru dari hasil belajar bersama dengan tajam, kuat, indah dan berkelanjutan.

6) Kerjasama dan fleksibilitas, tidak belajar meneliti sesuatu tetapi belajar dengan sesuatu, tidak membaca sesuatu tetapi membaca dengan sesuatu (in and trough).

Proses kreatif dalam mengembangkan ide besar suatu karya tidak semata-mata menghubugkan berbagai cerita yang dianggap menarik lalu dibuat karya, tetapi ada beberapa tahap atau pengendapan suatu ide. Persiapan pertama yang dilakukan penulis lebih cendrung menggunakan struktur mengembangkan kreativitas dari David Cambel ( Kiswandoro, 2000:12) yaitu: 1. Preparation (Persiapan), 2. Concentration (Konsentrasi), 3. Incubation (Inkubasi), 4. Illumination (Iluminasi), 5. Verivication (Produksi).

\section{a. Preparation (persiapan)}

Tahap di mana mencari bahan-bahan dari berbagai hal, yaitu pengumpulan dari kasuskasus yang sering penulis baca di berita harian dan berita online selain itu melihat dari permasalahan sosial hingga menjadi kumpulan bahan yang siap untuk data. Penulis juga mencari referensi yang relevan untuk menambah inspirasi seperti buku-buku, media cetak, internet, majalah dan sebagainya. Selanjutnya penulis melakukan pemilihan objek yang cocok, pemilihan bentuk vigur manusia sebagai objek dirasakan dapat mewakili gagasan yang diangkat sebagai ide bentuk penciptaan karya. Pada tahap persiapan ini menggunakan proses in and trough sebagai artistic research.

\section{b. Concentration (konsentrasi)}

Tahap pemusatan untuk menimbang pilihan yang tercurah, adanya pertimbanganpertimbangan menyangkut ide penciptaan adalah kunci pokok untuk mengetahui celah di mana keunggulan atau kelemahan dari ide yang diangkat. Perihal tersebut penting adanya untuk tahap konsentrasi dalam pematangan dan mengenali lebih jauh tentang beberapa kelemahan. Pada tahap konsentrasi ini menggunakan proses in and trough sebagai artistic research.

\section{c. Incubation (inkubasi)}

Mengambil waktu dan jarak untuk melepas persoalan yang dihadapi, merupakan tahap pematangan spiritual, membentuk suatu sintesis atau analogi baru sebagai alur dalam membangaun pondasi memperkokoh ide dan gagasan dalam berkarya seni. Pada proses ini penulis mencoba mengelaborasi kesatuan ide pokok, subjek, material dan cara penyajian dalam karya tersebut benar-benar akan dieksekusi. Pada tahap inkubasi ini menggunakan proses in and trough sebagai artistic research.

\section{d. Illumination (iluminasi)}

Tahap ketika mendapatkan ide, gagasan, penyelesaian serta cara kerja. Kesadarankesadaran muncul secara otomatis karena sudah menyatu dengan ide gagasan hingga dengan mudah menjawab atau menerangkan alur cerita ide besar dibalik karya tersebut. Pada tahap ini harus mempersiapkan beberapa referensi acuan karya yang mendekati atau menjadi panutan dalam proses pembentukan atau ide pembentukan hingga teknik berkarya seni. pengolahan uji coba hingga berhasil menemukan bentuk yang tepat dilakukan pada proses ini hingga menjadi matang dalam pemikiran maupun upaya penggagasan ide penciptaan sampai proses perwujudan. . Pada tahap iluminasi ini menggunakan proses in and trough sebagai artistic research.

\section{e. Verivication (produksi)}

Setelah mengetahui produk karya yang akan dihasilkan maka proses selanjutnya adalah proses produksi. Dalam prosesnya saya mengadopsi metode David Campbel tersebut ke bentuk yang lebih sederhana.

Proses penciptaan karya ini secara khusus terdiri dari dua tahap besar yaitu pembentukan konsep dan proses produksi. Setelah melalui tahap pengedapan dari tahap sebelumnya penulis mengembangkan berbagai kemungkinan aspek penciptaan, seperti pengembangan dari teknik, media, bentuk dan berbagai diskusi-diskusi sehingga melahirkan hal-hal baru. Pada tahap produksi ini menggunakan proses in and trough sebagai artistic research.

\section{KONSEP PERWUJUDAN. \\ A. Ide bentuk}

Ide bentuk merupakan hal utama yang menjadi tahap pembuatan sebuah karya. Pemilihan metafor yang tepat menjadi hal pendukung bagi seniman guna menyampaikan 
pesan atau wacana yang ingin di ungkapkan pada masyarakat atau apresian. perwujudan penulis mengungkapkan hal-hal yang berkaitan dengan wanita pekerja. penulis memvisualisasikan figurfigur atau objek-objek sesuai dengan tema dan konsep penulis angkat ke dalam lukisan. Dalam memvisualisasikan wanita pekerja, penulis menggambarkan sebagian besar adalah kehidupan atau kebiasaan yang penulis jumpai yakni kehidupan sosial wanita pekerja. Kondisi para wanita yang berkerja seperti pada pagi hari ataupun siang hari dan sore yakni seperti ibu-ibu yang menjadi buruh angkut dagang di pasar, wanita yang menggendong hasil mulung barang bekas di tempat pembuangan sampah, dan ibu-ibu menjual bakul.

Hal ini yang menjadi perhatian aktivitas yang dikerjakan oleh ibu atau istri untuk memenuhi kebutuhan keluarga. Padahal wanita bukan sebagai penopang utama untuk mencari rejeki, karena wanita tugas utama adalah sebagai ibu rumah tangga mempersiapkan segala hal berurusan dengan kerumahan namun karna faktor ekonomi dan kebutuhan yang mengharuskan wanita bekerja membantu suami dan mepunyai tanggung jawab bagi keluarga.

\section{B. Sifat Material, Teknik, dan Penyajian}

Setelah melakukan pemilihan metafor yang diginakan hal selanjutnya yaitu memilih material yang sesuai dengan tema yang diangkat. Kesesuain pemilihan material merupakan hal yang dapat mendukung penyampaian dan memberi kekuatan terhadap bentuk-bentuk yang ingin disampaikan. Tidak hanya sebagai penguat tetapi dapat juga mendukung penyampaian makna. Material, bentuk, dan konten adalah satu kesatuan dalam sebuah karya yang mestinya difikirkan oleh seniman.

Pada proses penciptaan karya penulis melakukan dua pendekatan yaitu pendekatan realisme dengan pengambilan bentuk objek atau figur manusia dengan meninjau ke tempat kejadian. Perupa menghadirkan bentuk figure wanita yang sedang bekerja sebagai representasi objek yang akan diangkat sesuai dengan bahasan dan konsep.

Pendekatan kedua yaitu pemilihan warna dan gaya dalam lukisan cendrung mengada-ada sebagai bentuk pencapai kesan pesan yang akan di sampaikan sehingga timbulah sebuah bentuk drama dalam lukisan tersebut dengan konsep yang di angkat sebelumnya.

\section{HASIL DAN PEMBAHASAN}

Setiap karya menciptakan apa yang terjadi pada suatu waktu, karna karya merupakan hasil pengekspresian dari seniman terhadap apa yag dialami atau dirasakan seniman tersebut. Tema dan konsep yang diangkat memngenai sosok wanita pekerja kerasyang menyalahi kondratnya sebagai seorang wanta seutuhnya permasalah tersebutlah yang penulis angkat sehingga terwujudnya suatu karya seni melalui proses pengamatan, perenungan, dan di visualkan kedalam bentuk garis warna dan objek-objek sesuai yang di inginkan. Karya-karya yang diciptakan merupakan ungkapan kegelisahan yang penulis rasakan terhadap masalah sosial yang terjadi. Dalam kesempatan ini penulis akan membahas karya-karya dalam bentuk tulisan agar dapat membantu penikmat seni memaknai karyakarya yang penulis hadirkan. Proses kreatif ini dapat terbaca dari beberapa contoh perwujudan karya di bawah ini.

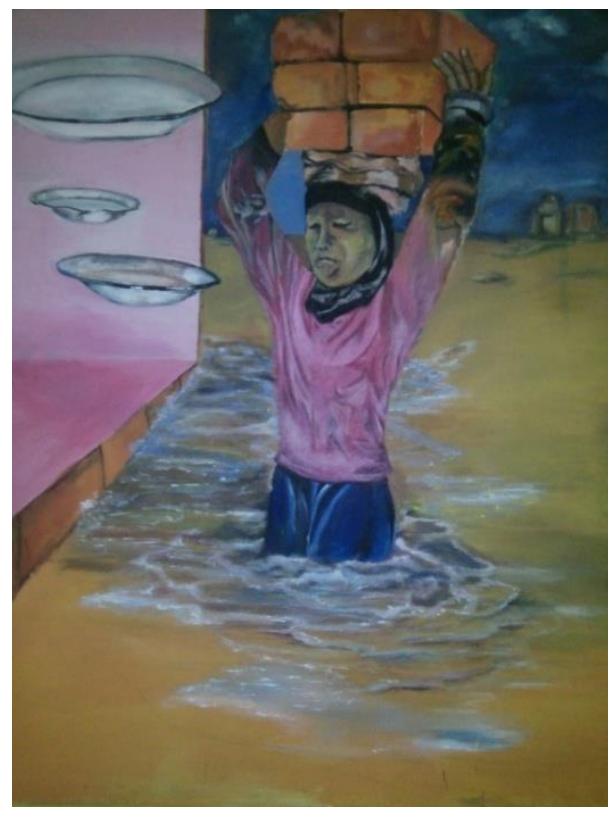

Judul : melawan rasa lelah

Ukuran: 120 x 100

Bahan : akrilik di atas kanvas

Tahun pembuata: 2017

Sumber: Seftian Hidayat

Pada karya ini penulis menampilkan seorang wanita sedang mengankat benda berupa bahan bangunan yakni batu bata sebagi subjek utama lukisan. Selain figure wanita yang sedang bekerja penulis menambahkan objek tambahan berupa tiga tempat wadah makan berupa piring yang melayang, dan bangunan berupa dinding. Dengan riakkan air yang menenggelamkan setengah badan bagian bawah pinggang, dan langit yang berwarna biru kelam. 
Batu-bata identik denganbahan banguan, pekerja bangunan sehurusnya dikerjakan oleh seorang lelaki karna lelaki memiliki fisik kuat. Namun bila seorang wanita yang menggeluti pekerjan ini tentunya sangat tidak biasa karna dilihat secara fisik, lelaki lebih kuat dari wanita. Karena kebutuhan yang harus di cukupi yang memaksa wanita ikut serta kerja.

Lukisan tersebut terdapat pula piringpiring yang melayang, menyimbolkan bahwa sesuatu yang harus diisi. Pada umunya fungsi piring merupakan tempat wadah makan artinya seorang yang bekerja tentunya memiliki tujuan , tujuan tersebut yakni mencukupi kebutuhan baik ekonomi maupun kebutuhan keluarga.

Dinding berbentuk ruangan yang berada dalam lukisan tersebut memberikan kesan sebuah bangun agar dapat memberi kesan bahwa wanita tersebut merupakan seorang pekerja bangunan. Air yang menenggelamkan saparuh tubuhnya merupakan makna dimana wanita tersebut tidak hanya melawan rasa lelah, namun wanita tersebut tetap bekrja keras.

Dalam karya pertama yang menampilkan seorang wanita dengan mengankat bahan bangunan berupa batu bata, menunjukan seorang pekerja keras yang seharusnya tidak di geluti oleh seorang wanita.Melawan rasa lelah judul yang di angkat merupakan suatu makna dimana seorang wanita yang terdapat jiwa perkasaa untuk bekerja keras membanting tulang demi menyongkong ekonomi keluarga.Lelah yang di rasakan adalah kawan sehari-hari namun demi memenuhi kebutuhan hidup rasa lelah pun tak dihiraukan.

Wanita yang seharusnya berperan sebagai ibu rumah tangga mengasuh dan merawat keluarga tetapi menjadi tulang punggung keluarga. Kebutuhan ekonomi merupakan kebutuhan pokok utama, demi mencapai kebutuhan tersebut seorang wanita yang mengharuskan bekrja danberperan menjadi ibu rumah tangga. Dalam hal ini pemerintah harus memperhatikan kaum wanita dengan menciptakan lapangan kerja yang layak agar masalah tersebut dapat di atasi.

Lukisan tersebut tidak terlepas pula dengan unsur dan prinsip pada seni rupa yakni titik, garis, bidang, gempal, tekstur dan warna. Lukisan tersebut dibuat dengan menggunakan prinsip yang ada seperti garis, garis yang di buat berbentuk vertical, horizontal, terdapat bentuk batasan antara dataran dan langit berwarna biru tua kemudian garis horizontal yakni terdapat pada bangunan yang tegak membentuk ruang dan garis vertical di bawahnya. Dan pada warna penulis menampilkan warna ping arti dari warna ping atau merah muda melambangkan prinsip feminim dan banyak disukai oleh wanita,auranya yang kuat memberi benak kita nuansa kelemah lembutan, peduli dan romansa.
Tekstur yang tergambar pada lukisan tersebut agak tegas kasar dan penuh ekspresif dan kesatuan merupakan seregaman warna yang di sesuaikan hingga menimbulkan gradasi warna.Keseimbangan yang sederajat dimana keseimbangan antara ruang sebelah kiri dan ruang sebelah kanan memiliki besaran sederajat, seperti diding ruang sebelah kiri tidak terlalu memakan ruang sehingga terliahat tidak terlalu sempit. Proposi yang di gambarkan di sesuaikan sehingga figure utama seorang wanita menjadi aksentuasi utama dan susunan bentuk dengan ukuran secara transisi membawa evek pandangan berhenti sejenak dan kemudian berkeliling keseluruh objek secara smood.

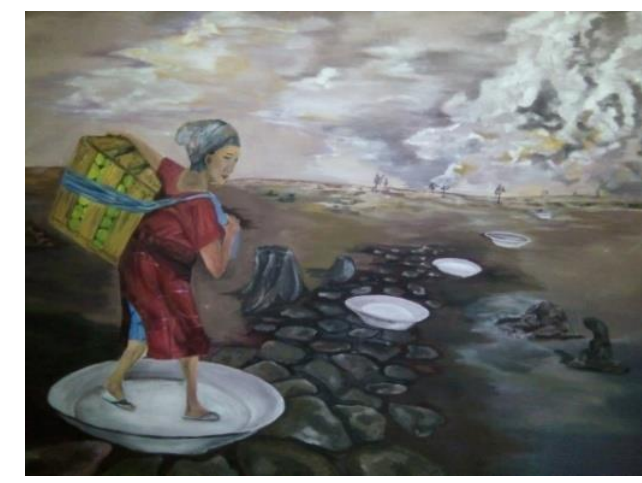

Judul : menjajapi satu demi satu Ukuran: $120 \times 100$

Bahan : akrilik di atas kanvas

Tahun pembuata: 2017

Sumber: Seftian Hidayat

Karya ketiga ini penulis memberi judul "menjajapi satu demi satu" secara visual karya tersebut menapilkan seorang wanita yang sedang menggendong sebuh kotak yang berisi buah dan beberapa jajaran piring yang ia pijak. Sebuah tempat yang luas dengan warna langit coklat menyerupai dataran.Awan yang menggumpal.Pada bagian kanan sedikit kesan dengan warna kuning.

Piring yang terdapat dalam lukisan tersebut mengartikan bahwa kebutuhan yang harus diisi satu demi satu. Pada dasarnya piring merupakan wadah makan, dan tempat untuk makan. Kebutahan manusia yakni sandang dan pangan maka dari itu penulis melambangkan piring yang di injak oleh seorang wanita yang sedang menggendong sebuah kotak yang berisi kayu, menceritakan bahwa wanita tersebut tengah berkerja keras demi memenuhi kebutuhan yang di lambangkan dengan sebuah piring. Kemudian komposisi dan keseimbangan asimetris tentunya sangat di pertimbangkan pada dasarnya keseimbangan asimetris yaitu keseimbangan ruang kiri dan kanan tidak memiliki beban sama besaran maupun bentuk rautnya tetapi tetap dalam keadaan seimbang. Figur pertama di letakan 
pada sisi kiri, dan di buat sedemikian rupa agar seimbang dan tidak terlalu banyak memakan ruang.

Pada lukisan tersebut menceritakan kebiasan wanita buruh angkut yang setiap pagi mengangkut Sebuah kotak berisi buah yang akan dijual. Menjadi pengangkut barang tentunya di perlukan tenaga yang kuat, dan kebanyakan menjadi pengangkut barang yakni lakilaki.Perempuan atau wanita yang berkerja sebagai buruh angkut.Menurut yang penulis jumpai Sebagian besar buruh angkut di pasar 16 linggau propinsi Sumatra selatan merupakan ibu rumah tangga yang berkerja demi memenuhi perekonomian keluarga, dan alasan lain yakni membantu suami. Selain itu pekerjaan sebagai buruh angkut hanya mengandalkan tenaga dan tidak mempunyai keahlian khusus.

Seorang wanita yang sebagai mana kodratnya mengurus keluarga dan mendidik anak, namun harus menjadi seorang pekerja.Makna seorang wanita yang berdiri di atas piring merupakan suatu ungkapan dimana wanita tersebut harus menjajapi dan memenuhi satu persatu kubutuhan yang di perlukan dalam keluarga.Makna piring yakni suatu wadah yang harus diisi, untuk mengisinya maka di ibaratkan seorang wanita yang berdiri di atas piring tersebut.

Dalam lukisan ke dua ini tidak terlepas pula dengan unsur dan prinsip pada seni rupa yakni titik, garis, bidang, gempal, tekstur dan warna.Dan prinsip-prinsip seni pada lukisan kali ini batasan yang terdapat pada lukisan tersebut antara dataran dan langit-langit membentuk garis horizontal namun sedikit terdapat lengkungan dan bidang berbentuk segi empat terdapat pada lukisan kotak berisikan buah dan bidang lingkaran berupa piring-piring.Tekstur merupakan nilai atau ciri khas suatu permukaan atau raut.Lukisan tersebut bertekstur sedikit kasar dan kurang halus dilihat dari ketebalan goresan cat dan bentuk awan.

Warna yang terdapat dalam lukisan tersebut berwarna coklat dari warna coklat terang hingga penurunan warna menuju coklat gelap dan warna putih. Banyaknya ruang kosong bermaksud agar karya tidak terlalu padat dalam penempatanya pada sebuah bidang sehingga poin of interest pada objek pertama yakni seorang wanita tersebut menjadi pusat perhatian.

Kesatuan merupakan hal yang utama, kesatuan dapat di capai jika salah satu atau beberpa unsur rupa mempunyai hubungan seperti warna yang dibuat sedemikian mungkin sehingga adanya gradasi dan keselarasan.Piring yang di gambarkan dengan berbeda ukuranya dibuat agar proporsi terhadap gambar tersebut terlihat, sehingga terbentuknya perspektif jauh dan keseimbangan terhadap objek pertamapun disesuaikan agar kesamaan intensitas warna nada, dan kesamaan arah dan gerak sesuai.

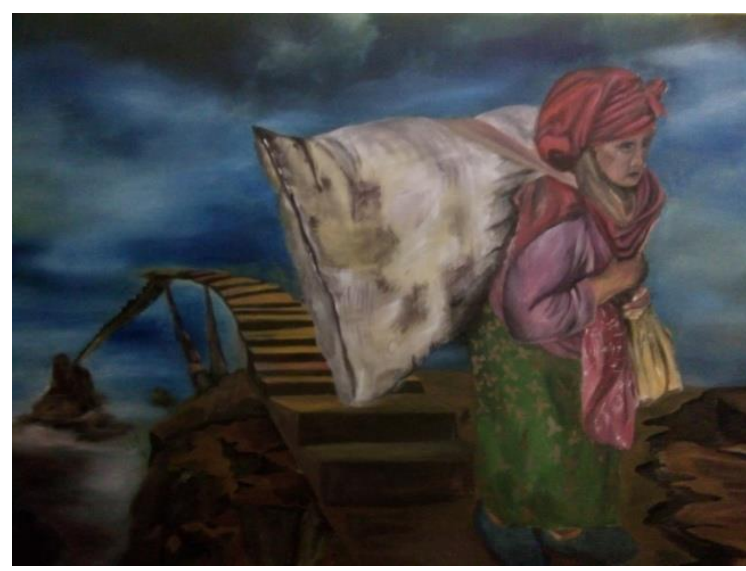

Judul : Menjadi Tulang punggung Ukuran: 140 x 100

Bahan : akrilik di atas kanvas

Tahun pembuata: 2017

Sumber: Seftian Hidayat

Lukisan ini secara visual menampilkan seorang wanita yang menggendong sebuah karung di atas pundaknya.Dan terdapat pula anak tangga yang menjulur dari satu tebing ke tebing yang berada di belakang wanita tersebut. Beban yang digendong dalam lukisan tersebut sangat berat sehingga penggambaran pada objek di buat sedikit membukuk dan pandangan muka yang tetap menuju kearah depan.

Pada lukisan ini penulis menceritakan tentang kerja keras.Menjadi tulang punggung bagi keluarga merupakan suatu kewajiban bagi seorang lelaki, dalam haknya ia harus menanggungjawapi kebutuhan terhadap keluarga, namun tidak semua lelaki yang harus menjadi tulang punggung bagi keluar melainkan wanita juga harus ikut serta menjadi tulang punggung keluarga. Istilah tulang punggung keluarga yakni orang yang berkerja keras di dalam sebuah keluarga untuk menghidupi keluarga tersebut. Dalam arti laintulang punggung berarti sesuatu yang menjadi pokok kekuatan, seorang yang bertanggung jawab.

Tangga yang kecil dan menyambung dengan dua tonggak mengartikan bahwa sebuah jarak dan usaha yang di tempuh memerlukan kekuatan dan fisik yang kuat, dengan menggendong beban seberat itu tentunya tidak mudah dan mustahil untuk dilalui, namun penulis mengungkapkannya dengan menggambarkan tangga tersebut. Dapat di simpulkan bawa setiap usaha dan kewajiban yang akan kita tanggung sangatlah tidak mudah, kerja keras dan kesabaran yang harus ditanamkan dalam diri agar tercapainya suatu usaha yang kita inginkan. 
Dalam lukisan ke lima ini tidak terlepas pula dengan unsur dan prinsip pada seni rupa yakni titik, garis, bidang, gempal, tekstur dan warna serta prinsip-prinsip seni. Diantara prinsip tersebut yakni keseimbangan dapat di bagi menjadi dua yakni keseimbangan simetris dan keseimbangan asimetris.Keseimbangan simetris tercapai jika dimunculkan melalui kesamaan intensitas warna atau nada sertakesamaan arah dan gerak. Sedangkan keseimbanga asimetris adalah keseimbangan yang tidak bergantung pada keadaan yang serba sama melainkan cara mengelolayang mahir dalam mengimbangi Sesuatu. Poin of interes tentunya pada figur seorang wanita yang sedang menggendong sebuah karung, garis zig-zag yang terdapat pada lerenglereng tebing dan tangga.

Pewarnaan yang terdapat pada lukisan tersebut mendominasi dengan warna biru, diantara warna biru tersebut tidak hanya biru saja yang di pakai melainkan warna yang beragam seperti biru muda, biru tua, biru kehijauan yang berada pada samping kanan.Bidang merupakan permukaan yang berbetuk pipih dan datar tanpa ketebalanyang memiliki ukuran panjang, lebar dan luas.

Gambar tangga yang dibuat dalam lukisan tersebut memliki bidang maya yakni bentuk bidang seolah meliuk, memiliki perspektif sehingga terlihat jarak antara objek utama.Warna yang diterapkan dimuat hanya semestiya mengingat bentuk dan propposi agar tidak terlihat padat maka di buat dengan sesederhana mungkin agar mendorong penikmat untuk menatap lama dan tidak jenuh.

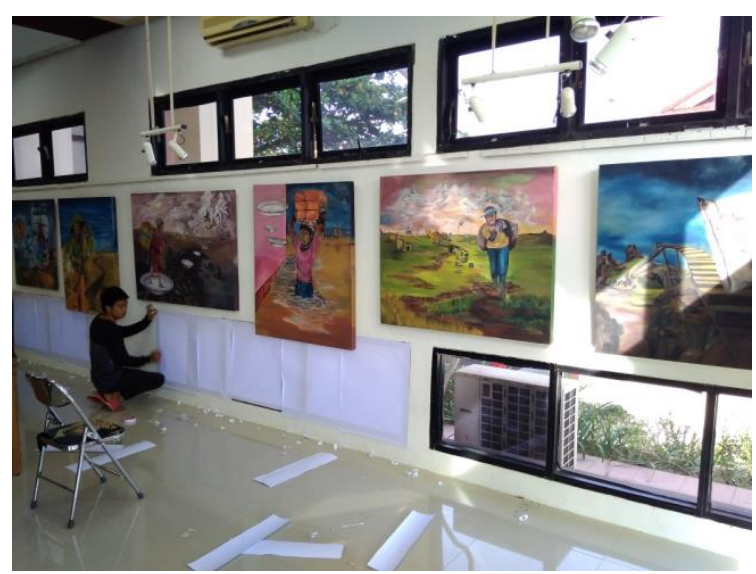

Gambar di atas meupakan persiapan berpameran di ruang galeri Fakulatas Bahasa dan Seni Universitas Negri Padang . pameran berlangsung selama tujuh hari tepatanya satu minggu dengan karya dan konsep yang penulis ambil yakni wanita pekerja keras dalam karya lukis realis kontemporer. Dengan jumlah karya sepuluh buah dan dalam masing masiang karya terdapat jududl sesuai dengan penggambaran yang di berikan sehingga sesuai dengan bentuk dan pencapaian yang di inginkan tanpa keluar dari konsep yang diangkat.

\section{KESIMPULAN}

Umumnya wanita mempunyai dua peranan pertama, sebagai istri dan ibu rumah tangga dan kedua, sebagai partner untuk mencari nafkah bagi kehidupan rumah tangganya. Kewajiban wanita dalam rumah tangga adalah mengatur dan memperhatikan kegiatan rumah tangga. Sementara itu hak mereka adalah menentukan dan mengatur anggaran belanja, mengatur menu makanan, dan lain-lain yang berkaitan dengan kerumahtanggaan.

Namun penyebab terjadinya mengapa seoarang wanita menjadi pekerja dengan meninggalkan peranannya. Ekonomi yang menjadikan alasan utama seorang wanita harus berkerja, namun selain alasan ekonomi masih ada faktor yang melatarbelakangi di antaranya faktor sosial dan faktor pendorong mengapa seorang wanita harus berkerja yakni adanya keinginan untuk membantu keluarga, dan membantu suami mencukupi kebutuhan ekonomi keluarga.

Melalui media visual penulis berupaya menjadikan karya lukis sebagai wadah untuk menyampaikan informasi tentang fenomenafenomena masalah sosial yang terjadi dalam kehidupan ini. Penulis berupaya menampilkan bentuk-bentuk yang dipahami agar makna yang terkandung dapat tersampaikan dan tidak terabaikan dalam karya tersebut penulis tampilkan dengan gaya atau aliran surealis. gaya surealis merupakan gaya atau aliran seni sesustraan yang menjelajahi dan merayakan alam mimpi dan fikiran bawah sadar melalui penciptaan kaya fisual.

Masalah sosial yang terjadi merupakan bahan utama yang penulis angkat sebagai konsep berkarya dengan bertujuan agar kegelisahankegelisahan yang terdapat di dalam kehidupan dapat tersampaikan. Kebijakan pemerintah tentunya sangat di perlukan agar bisa memberi kebijakan terhadap masalah-masalah yang ada terutama memberikan lapangan pekerjaan yang layak dan sesuai untuk meningkatkan kesejahteraan masyarakat.

\section{DAFTAR PUSTAKA}

Ernawati, E. (2020). PSIKOLOGIS DALAM SENI: KATARSIS SEBAGAI REPRESENTASI DALAM KARYA SENI RUPA. DESKOVI: Art and Design Journal, 2(2), 105-112.

Istiawati, Kiswandono,( 2000). "Berpikir Kreatif Suatu Pendekatan Menuju Berpikir Arsitektural, DIMENSI 
TEKNIK ARSITEKTUR" Vol. 28, No. 1, Juli 2000: 816 puslit.petra.ac.id./journals/architecture.

Hanual, M. Ssuoronta, J. Vaden, T, (2005). Artistic Research Theoris methods And Practice. Findland Cosmoprint $0 y$.

Mustafah Ibnu .1997.keluarga islam menyongsong abad 21.Bandung :AlBayan http://www.dakwatuna.com/2014/05/08/5093 7/wanita-dan-kodratnya/\#ixzz4LwMkdd5F : @dakwatuna on Twitter | dakwatunacom on Facebook

kompas, 2013." Perempuan bekerja sebuah dilemma perubahan zaman "(https://www.kompasiana.com/renaldi.wicakso no/ di akses 9 Desember 2017 10:25 AM) 